\section{AMERICAN-EURASIAN JOURNAL OF SUSTAINABLE AGRICULTURE}

\title{
Physiological properties, growth, and yield of shallot (Allium cepa var. Aggregatum) in coastal sand land with inoculation of Trichoderma asperellum and cow manure
}

\author{
Tuti Setyaningrum*1, Didik Indradewa ${ }^{2}$, Achmadi Priyatmojo ${ }^{2}$, Endang Sulistyaningsih ${ }^{2}$ \\ ${ }^{1}$ Agriculture Faculty, University of Pembangunan Nasional “Veteran” Yogyakarta \\ ${ }^{2}$ Agriculture Faculty, Gadjah Mada University, Yogyakarta
}

Received date: 18 September 2018, Accepted date: 15 November 2018, Online date: 20 December 2018

\author{
Address for Correspondence: \\ Tuti Setyaningrum, Agriculture Faculty, University of Pembangunan Nasional "Veteran” Yogyakarta \\ E-mail: tutisetia18@yahoo.com
}

Copyright $@ 2018$ by authors and American-Eurasian Network for Scientific Information.

This work is licensed under the Creative Commons Attribution International License (CC BY).

http://creativecommons.org/licenses/by/4.0/

\section{(c) (i) Open Access}

\begin{abstract}
To meet the needs of shallots, one of the horticultural commodities that is a mainstay of Indonesia's regional and national commodities, needs to increase yields. One way that can be taken is through land expansion. In Indonesia, coastal sand land is a potential land for the development of crop cultivation, especially shallots. To improve the quality of coastal sand land as a planting medium, cow manure is used as soil ameliorant organic matter. Trichoderma asperellum, one of the plant growth promoting fungi (PGPF), is used to increase plant growth

This experiment aims to study physiological characters, growth and yield of several shallots cultivars planted in coastal sand, with inoculation of Trichoderma asperellum and the addition of organic material in the form of cow manure, so that cultivars can be determined which have good growth and yield.

This research was carried out on the beach sand in Samas area, Bantul Regency, Yogyakarta, starting November 2017 to January 2018. This field experiment consisting of two factors and arranged in a completely randomized block design with three replications. The first factor is shallots cultivar which consists of four cultivars, namely: Bauji, Tajuk, Manjoung, and Bima Brebes. The second factor is the dose of organic matter in the form of cow manure: $(0,10,20$ and 30)ton/ha. Data from observations were analyzed statistically using analysis of variance, followed by Duncan's multiple range test.

Various cultivars tested have a various of total chlorophyll content in leaves, plant height, total dry weight/plant and the dry weight of air-dried bulbs/ha, but it does not have a number of leaves that is significantly different. The application of cow manure with a dose of 10, 20, 30 tons/ha does not produce a total chlorophyll content in leaves, number of leaves and total dry weight/plant that are significantly different from without fertilization, but it produces a variety of plant height and the dry weight of air-dried bulbs/ha.

From this study it can be concluded that from various cultivars tested, showed a significant difference in total chlorophyll levels, plant height, total dry weight per plant and weight of air-dried bulbs per hectare. Bima Brebes cultivar has the heaviest weight of air-dried bulbs per hectare. The dose of fertilizer 30 tons per hectare yield the heaviest weight of air-dried bulbs, although not significantly different from the dose of 20 tons per hectare.

KEY WORDS

Coastal sand land, Cow manure, Shallot, Trichoderma asperellum.
\end{abstract}

\section{INTRODUCTION}

Besides being known as the main spice of almost all Indonesian dishes, shallot also has various health benefits due to its nutritional content. In terms of the fulfillment of national consumption, farmers' income sources, as well as its potential as a foreign exchange earner, shallots are a type of commodity that has high 
economic value [1]. The need for shallots will continue to increase along with the increase in population.To meet the needs of shallots in Indonesia, it is always necessary to increase the yield of shallots that can be taken through the expansion of new areas and increased productivity [2]. Coastal sand is a sub-optimal land that has the potential to be developed as agricultural land, including for the expansion of shallot planting areas. According to Yuwono [3], the Province of Yogyakarta Special Region (DIY) has a coastal sand area of about 3,300 hectares (4\% of the total area), stretching $110 \mathrm{~km}$ along the southern coast of the Indonesian Sea. Based on physical and biological properties, coastal land with a sand content of more than $85 \%$, coarse and easily eroded soil texture causes its ability to absorb and store water is low, the nutrient binding ability is also low. Other constraints that may be found are low organic matter content, and high air temperature, so that land productivity is low $[4,3,5]$.

Organic matter, soil constituent parts which are less than 10\%, but are very important in the context of plant nutrition. Organic matter contributes most of the nutrients needed by plants (N, P, and S), especially those not given outside inputs [6]. According to Delvian [7], organic fertilizers can increase plant growth and beneficial soil microbial populations. One of the advantages of organic matter is that it retains water, which has the effect of helping to prevent dryness. Organic fertilizers can improve the ability to maintain moisture in sandy soil, and its mineralized properties have an effect as a source of nutrients for plant growth. Organic matter also maintains physical, chemic and biological conditions for sustainable crop yield [6]. In sandy soil, organic matter can be expected to change the soil structure from single grained to lumpy form, thereby increasing the degree of structure and size of the aggregate or increasing the class structure from fine to moderate or rough [8]. The results of the Partoyo study[9], show that based on the soil quality index value, the addition of clay and manure treatment can improve soil quality.The commodities that are established in the soil amelioration technology that have been applied are mainly shallots and red chili which are the mainstay of national and regional commodities [3].

In sustainable agriculture, various approaches and techniques are shown to reduce environmental impacts. One such strategy is the use of soil micro-organisms to promote plant growth and control plant diseases [10]. Trichoderma sp. is one of the fungi, includes Plant Growth Promoting Fungi (PGPF), non-pathogenic fungi in the soil which are reported to be beneficial for some plants through their role in promotting growth and also protecting plants from pathogenic attacks [11]. Trichoderma sp. has been widely investigated for its use in various types of commodities, including its potential use as biological control agents against anthracnose in mangoes [12], the effect of the Trichoderma harzianum strain on the growth of tomato seeds [13], the effect of Trichoderma harizanum to control damping off and growth boosters in Capsicum annuum [14], the effectiveness of the dose and time of application of Trichoderma virens to the attack of Sclerotium rolfsii in soybeans [15], and Trichoderma harzianum as promoter of plant growth in wheat [16]. The use of Trichoderma sp. and the application of cow manure in coastal sand lands is expected to increase the growth and yield of shallots. The purpose of this experiment is to study physiological characters, growth and yield of several shallots cultivars planted in coastal sand, with inoculation of Trichoderma asperellum and application of organic matter in the form of cow manure.

\section{MATERIALS AND METHODS}

This research was conducted on the Samas Beach area, Bantul Regency, Special Region of Yogyakarta, from November 2017 to January 2018. This research is a field experiment, consisting of two factors and arranged in a completely randomized block design (CRBD) with three replications. The first factor is shallot cultivars, consisting of four types, namely: K1 (Bauji), K2 (Tajuk), K3 (Manjoung), and K4 (Bima Brebes). The second factor is the dose of organic matter in the form of cow manure: B0 (0 ton / ha), B1 (10 ton / ha), B2 (20 ton / ha), dan B3 (30 ton / ha). Data from observations were analyzed statistically using analysis of variance (ANOVA), followed by Duncan's multiple range test (DMRT) at the level of 5\%.

N-P-K fertilizer (16-16-16) with a dose of $200 \mathrm{Kg} / \mathrm{ha}$ was given 7 days after planting, also, additional fertilizer was provided with $60 \mathrm{~kg} / \mathrm{ha}$ of $\mathrm{ZA}$ and $50 \mathrm{~kg} \mathrm{KCl} / \mathrm{ha}$. Trichoderma used in this study was Trichoderma asperellum, a collection from the Control Technology Laboratory, HPT Dept., Faculty of Agriculture, UGM, Yogyakarta. Trichoderma asperellum fungal culture inoculation was carried out by 50 grams of culture per plant inserted in sand soil media on a plot area of $2.3 \mathrm{~m}^{2}$, three days before planting. 
Tuti Setyaningrum., 2018. Physiological properties, growth, and yield of shallot (Allium cepa var. Aggregatum) in coastal sand land with inoculation of Trichoderma asperellum and cow manure American-Eurasian Journal of Sustainable Agriculture. 12(4) October-December 2018, Pages: 25-33. DOI: 10.22587/aejsa.2018.12.4.4

The soil and manure conditions before treatment

Table 1. The soil conditions before treatment and nutrient content in cow manure

\begin{tabular}{|c|c|c|c|c|}
\hline \multicolumn{5}{|c|}{ Soil conditions before treatment } \\
\hline C-org & N-available & P-available & K-available & $\mathrm{CEC}$ \\
\hline $\mathrm{mg} \cdot \mathrm{kg}^{-1}$ & $\mathrm{mg} \cdot \mathrm{kg}^{-1}$ & mg. $\mathrm{kg}^{-1}$ & mg. $\mathrm{kg}^{-1}$ & $\mathrm{Cmol}(+) \mathrm{kg}^{-1}$ \\
\hline 0.2937 & 0.0209 & 27.0412 & 0.2849 & 1.0053 \\
\hline Very low & Very low & Very high & Very low & Very low \\
\hline \multicolumn{5}{|c|}{ Nutrient content in cow manure } \\
\hline C-organic & $\mathrm{N}$ & $\mathrm{P}_{2} \mathrm{O}_{5}$ & $\mathrm{~K}_{2} \mathrm{O}$ & CEC \\
\hline $\mathrm{mg} \cdot \mathrm{kg}^{-1}$ & $\mathrm{mg} \cdot \mathrm{kg}^{-1}$ & mg.kg ${ }^{-1}$ & mg. $\mathrm{kg}^{-1}$ & $\mathrm{Cmol}(+) \mathrm{kg}^{-1}$ \\
\hline 30.7449 & 0.0209 & 2.2401 & 1.4651 & 52.0234 \\
\hline Very high & Very low & Very low & Very low & Very high \\
\hline
\end{tabular}

Before being used in research, an analysis of the chemical properties of soil and cow manure was carried out. The soil conditions at the time before planting, the C-organic content, is very low, as well as $\mathrm{N}$ and $\mathrm{K}$ available and CEC, while the P-available content is very high (Table 1). This is almost the same as the results of the study of Rajiman et al. [17] in Bugel coastal sand lands, which show that coastal sand land has CEC, organic matter, and $\mathrm{C}$-organic very low, $\mathrm{N}$ and $\mathrm{K}$ are low, moderate $\mathrm{P}$-available, and total $\mathrm{P}$ is very high. According to Yulipriyanto [6], sandy soils generally contain less organic matter and nitrogen than on finetextured soils, because sand-soils have low moisture, easy to oxidize, addition of plant remnants naturally, less. Cation exchange capacity (CEC) shows the ability of the soil to hold cations and exchange these cations including plant nutrient cations. Cation exchange capacity is important for soil fertility [18]. The high Pavailable on the land used in this study, allegedly because the planting land on the Samas Coast has long been used as cultivation land, and has been given a lot of soil enhancers. The organic matter used in this study is cow manure. The results of the laboratory analysis of nutrient composition in cow manure used in this study are presented in Table 1. The table shows that the C-organic content and CEC in cow manure used is very high, while the $\mathrm{N}, \mathrm{P}_{2} \mathrm{O}_{5}$ and $\mathrm{K}_{2} \mathrm{O}$ elements are very low. A material with a high CEC value indicates that the material has a high ability to absorb and exchange or release back into the soil solution [19].

\section{RESULTS AND DISCUSSION}

The population of Trichoderma asperellum

Table 2. The population of Trichoderma asperellum (.103 cfu) in growing media of various shallots cultivars and various doses of cow manure, 35 days after planting and at harvest

\begin{tabular}{|c|c|c|c|c|c|}
\hline & \multicolumn{7}{|c|}{ Cultivar } & \\
\hline Manure dosage & Bauji & Tajuk & Manjoung & Bima Brebes & Average \\
\hline \multicolumn{7}{|c|}{35 days after planting } \\
\hline 0 ton/ha & $6.00 \mathrm{bcd}$ & $5.00 \mathrm{~cd}$ & $6.33 \mathrm{bcd}$ & $18.00 \mathrm{a}$ & 8.83 \\
\hline $10 \mathrm{ton} / \mathrm{ha}$ & $13.00 \mathrm{ab}$ & $4.33 \mathrm{~cd}$ & $3.33 \mathrm{~d}$ & $4.67 \mathrm{~cd}$ & 6.33 \\
\hline $20 \mathrm{ton} / \mathrm{ha}$ & $6.33 \mathrm{bcd}$ & $5.00 \mathrm{~cd}$ & $10.00 \mathrm{bcd}$ & $5.67 \mathrm{bcd}$ & 6.75 \\
\hline 30 ton/ha & $4.33 \mathrm{~cd}$ & $6.33 \mathrm{bcd}$ & $5.67 \mathrm{bcd}$ & $11.67 \mathrm{abc}$ & 7.00 \\
\hline Average & 7.42 & 5.17 & 6.33 & 10.00 & $(+)$ \\
\hline \multicolumn{7}{|c|}{ At harvest } & 7.33 & $5.33 \mathrm{a}$ \\
\hline 0 ton/ha & 3.00 & 3.00 & 8.00 & 4.67 & $3.25 \mathrm{a}$ \\
\hline 10 ton/ha & 3.00 & 2.67 & 2.67 & 4.00 & $3.08 \mathrm{a}$ \\
\hline 20 ton/ha & 3.67 & 1.67 & 3.00 & 3.67 \\
\hline 30 ton/ha & 3.00 & 5.00 & 2.33 & $\mathrm{a}$ \\
\hline Average & $3.17 \mathrm{p}$ & $3.08 \mathrm{p}$ & $4.00 \mathrm{p}$ & $4.92 \mathrm{p}$ & \\
\hline Mean values followed by the same letters show no significant difference by DMRT (p: 0.05$)$ \\
\hline \multicolumn{7}{|c|}{$(+):$ interaction between treatments } \\
\hline
\end{tabular}

The population of Trichoderma asperellum in the planting medium before treatment was $2,00.10^{3} \mathrm{cfu}$ (colony forming unit). At 35 days after planting, on Bauji cultivars, application of manure at the dose of 10 
Tuti Setyaningrum., 2018. Physiological properties, growth, and yield of shallot (Allium cepa var. Aggregatum) in coastal sand land with inoculation of Trichoderma asperellum and cow manure American-Eurasian Journal of Sustainable Agriculture. 12(4) October-December 2018, Pages: 25-33. DOI: 10.22587/aejsa.2018.12.4.4

tons/ha showed the highest population of Trichoderma asperellum in growing media. In Tajuk and Manjoung cultivars, application of manure at doses 10, 20 and 30 tons/ha, did not show the amount of the population of Trichoderma asperellum in the planting media which was significantly different than without the addition of manure. In Bima Brebes cultivar, giving manure at a rate of 30 tons/ha showed the highest population of Trichoderma asperellum in planting media, but not significantly different from without manure (Table 2). This indicates that in Bauji cultivars, with fertilizer dosages of 10 tons/ha, Trichoderma asperellum is able to make good use of available organic matter, so that can grow and resulting the most population. Increasing doses of manure, resulting in a greater content of organic material, so it is more widely used by various types of microorganisms in the soil and the consequences, there is a competition between Trichoderma asperellum and various microorganisms in utilizing available organic matters. According to Jangiam et al., certain soil properties and indigenous soil microbial populations often act as constraints to the establishment of microorganisms. At the Bima Brebes cultivar, without the provision of manure, Trichoderma asperellum is able to utilize available organic matters so that it produces the highest number of population in the growing media.With increasing doses, it is also possible to compete with various other microorganisms, so that the population decreases, and at the dose of 30 tons/ha Trichoderma asperellum is able to develop well and produce the highest number of population. This is in accordance with Chirinda statement [21], that changes in input of organic matter can affect crop yields and soil properties, depends on nutrient mineral supply to plants. Increased microbial activity follows an increase in $\mathrm{C}$ and $\mathrm{N}$ inputs in the planting system. These organic matters can be in the form of plant litter, compost and manure, which are very important for microbial life [22].

At harvest time, the population of Trichoderma asperellum in the growing media of various cultivars tested did not show any significant differences. As well on application cow manure at the rate of 10, 20 to 30 tons per hectare showed the population of Trichoderma asperellum in planting media that was not significantly different from without manure (Table 2). Compared to the condition before planting, the population of Trichoderma asperellum after harvest showed an increase, but less than at 35 days after planting. This is possible because the available organic matter has also been widely used by shallot plants for its growth. Sridianti [23] revealed that fungi help decompose organic matter to release nutrients and make nutritious food for other organisms. According to Tisdel and Nelson (1975) in Atmojo[24], the role of organic matter on nutrient availability in the soil is inseparable from the mineralization process which is the final stage of the process of reforming organic matter. In this process, complete plant nutrient minerals will be released $(\mathrm{N}, \mathrm{P}, \mathrm{K}, \mathrm{Ca}, \mathrm{Mg}$ and $\mathrm{S}$, also micronutrients). Nutrients $\mathrm{N}, \mathrm{P}$, and $\mathrm{S}$ are nutrients that are relatively more to be released and can be used by plants.

The condition of the chemical properties of the soil during the maximum vegetative growth of the plant Table 3. The conditions of chemical properties of the soil during the maximum vegetative growth of plants

\begin{tabular}{|c|c|c|c|c|c|c|}
\hline \multicolumn{2}{|c|}{ Treatment } & C-org & $\mathrm{N}$-available & P-available & K-available & $\mathrm{CEC}$ \\
\hline \multirow[t]{2}{*}{ Cultivar } & Manure & & & & & \\
\hline & Ton/ha & $\mathrm{mg} \cdot \mathrm{kg}^{-1}$ & $\mathrm{mg} \cdot \mathrm{kg}^{-1}$ & $\mathrm{mg} \cdot \mathrm{kg}^{-1}$ & $\mathrm{mg} \cdot \mathrm{kg}^{-1}$ & $\begin{array}{c}\mathrm{Cmol}(+) \\
\mathrm{kg}^{-1}\end{array}$ \\
\hline \multirow{4}{*}{ Bauji } & 0 & 0,4082 & 0,3755 & 38,7748 & 0,8078 & 2,1234 \\
\hline & 10 & 0,5226 & 0,1643 & 38,4127 & 0,6653 & 1,6768 \\
\hline & 20 & 0,5558 & 0,3525 & 43,7845 & 0,6819 & 1,6783 \\
\hline & 30 & 0,5065 & 0,5793 & 35,4839 & 0,9352 & 1,7894 \\
\hline \multirow{4}{*}{ Tajuk } & 0 & 0,5778 & 0,4772 & 39,9141 & 0,9820 & 1,5646 \\
\hline & 10 & 0,5558 & 0,3838 & 41,6834 & 0,8086 & 1,3428 \\
\hline & 20 & 0,6702 & 0,4465 & 42,0270 & 0,8246 & 1,4546 \\
\hline & 30 & 0,6867 & 0,3760 & 47,3039 & 0,9518 & 1,4546 \\
\hline \multirow{4}{*}{ Manjoung } & 0 & 0,5881 & 0,6027 & 45,5164 & 0,9034 & 1,7891 \\
\hline & 10 & 0,5719 & 0,5403 & 41,4496 & 0,7292 & 1,4540 \\
\hline & 20 & 0,5388 & 0,3755 & 43,2178 & 0,6653 & 1,7884 \\
\hline & 30 & 0,9516 & 0,2354 & 41,8401 & 1,0815 & 1,9080 \\
\hline \multirow{4}{*}{ Bima Brebes } & 0 & 0,6374 & 0,2896 & 31,6578 & 0,9196 & 1,5658 \\
\hline & 10 & 0,5397 & 0,3838 & 36,9361 & 0,9198 & 2,0150 \\
\hline & 20 & 0,5228 & 0,5322 & 31,6316 & 0,6656 & 1,4536 \\
\hline & 30 & 0,6533 & 0,3051 & 46,0592 & 0,7290 & 1,5652 \\
\hline
\end{tabular}

The analysis was carried out at the Soil Nutrition and Fertilizer Technology Laboratory, Faculty of Agriculture, UPN "Veteran" Yogyakarta 
Tuti Setyaningrum., 2018. Physiological properties, growth, and yield of shallot (Allium cepa var. Aggregatum) in coastal sand land with inoculation of Trichoderma asperellum and cow manure American-Eurasian Journal of Sustainable Agriculture. 12(4) October-December 2018, Pages: 25-33. DOI: 10.22587/aejsa.2018.12.4.4

The addition of organic matter in the form of cow manure can improve soil fertility, seen from the increase in soil C-organic content and N-P-K available during the maximum vegetative period of the plant compared to the initial soil conditions, although there was no significant difference between treatments (Tables 1 and 3 ). This is likely to occur because the addition of cow manure can be used by Trichoderma asperellum to develop and improve its activities. Sridianti [23] states that fungi secrete enzymes into the environment and decompose organic matter, then absorb the nutrients of small particles through their cell membranes. With the development of the fungal population including Trichoderma asperellum, its activities related to the decomposition of organic matter are increasing, thus increasing soil fertility.

The CEC of a land represents the total amount of exchangeable cations that can be adsorbed by the soil. Cations on CEC from these soil particles are easily exchanged with other cations and as a result, they are available for plants [25]. The low soil CEC during the plant's maximum vegetative period shows that the soil has decreased its ability to absorb and exchange or release plant nutrient cations back into the soil solution, because of a large amount of nutrients absorbed by the shallot plants.

The condition of the chemical properties of the soil at harvest

Table 4. The condition of chemical properties of the soil at harvest

\begin{tabular}{|c|c|c|c|c|}
\hline \multicolumn{2}{|c|}{ Treatment } & N-available & P-available & K-available \\
\hline Cultivar & Manure & & & ${\mathrm{mg} \cdot \mathrm{kg}^{-1}}^{-1}$ \\
\hline & Ton/ha & $\mathrm{mg} \cdot \mathrm{kg}^{-1}$ & $\mathrm{mg} \cdot \mathrm{kg}^{-1}$ & 0,3008 \\
\hline Bauji & 0 & 0,0046 & 31,5750 & 0,2374 \\
\hline & 10 & 0,0038 & 21,2756 & 0,2689 \\
\hline & 20 & 0,0038 & 22,9011 & 0,3168 \\
\hline & 30 & 0,0046 & 27,1306 & 0,2691 \\
\hline Tajuk & 0 & 0,0046 & 28,3869 & 0,2534 \\
\hline & 10 & 0,0046 & 23,9758 & 0,2850 \\
\hline & 20 & 0,0043 & 22,1283 & 0,2691 \\
\hline Manjoung & 30 & 0,0037 & 23,2782 & 0,2848 \\
\hline & 0 & 0,0040 & 22,2157 & 0,3323 \\
\hline & 10 & 0,0048 & 21,9018 & 0,2532 \\
\hline & 20 & 0,0043 & 27,7045 & 0,2375 \\
\hline & 30 & 0,0045 & 23,6676 & 0,2692 \\
\hline & 0 & 0,0049 & 24,3625 & 0,2532 \\
\hline & 10 & 0,0049 & 20,0855 & 0,2532 \\
\hline & 20 & 0,0051 & 24,6821 & 0,2533 \\
\hline
\end{tabular}

The analysis was carried out at the Soil Nutrition and Fertilizer Technology Laboratory, Faculty of Agriculture, UPN "Veteran" Yogyakarta

At harvest, N-P-K available levels in the soil decreased compared to the maximum vegetative period of the plant. $\mathrm{N}$-available levels appear to have the most decreases so they are less than the initial soil conditions (Table 1,3,4). Reduced nutrient levels can be associated with plant uptake of these nutrients for growth and development, including for the formation of chlorophyll. Chlorophyll is a very important part of a plant, because of its role in photosynthesis. Several factors influence the presence of chlorophyll in a plant, i.e. presence of sunlight, carbohydrates, oxygen, nitrogen, magnesium and iron, water, and temperature [26].

On the other hand, the presence of Trichoderma asperellum can increase $\mathrm{N}$ uptake by plants, related to the role of these fungi as a plant growth-promoting fungi. This is in line with the statement of Jangiam et al. [20] that the application of plant growth-promoting (PGP) bacteria can increase plant capacity to utilize N-fertilizer efficiently.

\section{N, P, K Uptake}

The various cultivars tested did not show diverse uptake of N, P and K elements, in plants. Provision of cow manure with the dose of 10, 20 to 30 tons per hectare shows N, P and K elemental uptake in plants, which were not significantly different from without manure (Table 5).

Nutrient uptake by plants depends on nutrient concentration in the soil. Availability of nutrients in the soil is influenced by the rate of mineralization of organic matter. There is no difference in nutrient uptake by plants at 
Tuti Setyaningrum., 2018. Physiological properties, growth, and yield of shallot (Allium cepa var. Aggregatum) in coastal sand land with inoculation of Trichoderma asperellum and cow manure American-Eurasian Journal of Sustainable Agriculture. 12(4) October-December 2018, Pages: 25-33. DOI: 10.22587/aejsa.2018.12.4.4

various doses of cow manure and without fertilization. It could be because it hasn't been decomposed properly. According to Yulipriyanto [6], so that the function of organic matter can be maximized, organic matter must be prepared to be decomposed and continue to be mixed with fresh organic residues. The ability of the material to decompose depends on the physical condition or composition. The material will decay slowly if it is too hard, the structure is too tight, too dry or wet for the entry of microorganisms, oxygen, and nutrients. Weathering rates also depend on environmental factors.

Table 5. The elemental uptake of $\mathrm{N}, \mathrm{P}, \mathrm{K}$ by various shallots cultivars at various doses of cow manure (mg/plant)

\begin{tabular}{|c|c|c|c|c|c|}
\hline & \multicolumn{4}{|c|}{ Cultivar } & \multirow[b]{2}{*}{ Average } \\
\hline Manure dosage & Bauji & Tajuk & Manjoung & Bima Brebes & \\
\hline \multicolumn{6}{|c|}{ N-element uptake } \\
\hline 0 ton/ha & 2.92 & 4.49 & 4.48 & 5.40 & $4.32 \mathrm{a}$ \\
\hline 10 ton/ha & 5.27 & 4.61 & 5.35 & 3.31 & $4.64 \mathrm{a}$ \\
\hline 20 ton/ha & 4.99 & 5.71 & 3.73 & 5.60 & $5.01 \mathrm{a}$ \\
\hline 30 ton/ha & 4.94 & 6.39 & 5.37 & 5.68 & $5.60 \mathrm{a}$ \\
\hline Average & $4.53 \mathrm{p}$ & $5.30 \mathrm{p}$ & $4.74 \mathrm{p}$ & $5.00 \mathrm{p}$ & $(-)$ \\
\hline \multicolumn{6}{|c|}{ P-element uptake } \\
\hline 0 ton/ha & 1.09 & 1.71 & 1.55 & 1.91 & $1.56 \mathrm{a}$ \\
\hline 10 ton/ha & 1.83 & 1.48 & 1.74 & 1.75 & $1.70 \mathrm{a}$ \\
\hline 20 ton/ha & 1.45 & 2.59 & 1.51 & 1.70 & $1.81 \mathrm{a}$ \\
\hline 30 ton/ha & 1.20 & 2.27 & 2.51 & 2.17 & $2.04 \mathrm{a}$ \\
\hline Average & $1.39 \mathrm{p}$ & $2.01 \mathrm{p}$ & $1.83 \mathrm{p}$ & $1.88 \mathrm{p}$ & $(-)$ \\
\hline \multicolumn{6}{|c|}{ K-element uptake } \\
\hline 0 ton/ha & 3.33 & 4.45 & 5.23 & 4.83 & $4.46 \mathrm{a}$ \\
\hline 10 ton/ha & 3.41 & 4.09 & 4.77 & 5.14 & $4.36 \mathrm{a}$ \\
\hline 20 ton/ha & 3.80 & 6.47 & 3.87 & 3.17 & $4.33 \mathrm{a}$ \\
\hline 30 ton/ha & 4.06 & 5.95 & 10.77 & 4.35 & $6.28 \mathrm{a}$ \\
\hline Average & $3.65 \mathrm{p}$ & $5.24 \mathrm{p}$ & $6.16 \mathrm{p}$ & $4.37 \mathrm{p}$ & $(-)$ \\
\hline
\end{tabular}

\section{Physiological response and growth of plants}

Bauji cultivars showed the highest total chlorophyll levels in leaves, although not significantly different from Tajuk cultivars. The Bima Brebes cultivar had the lowest total chlorophyll content on the leaves, although it was not significantly different from Manjoung. Plants that are treated with cow manure or not, have total chlorophyll levels in the leaves, which are not significantly different (Table 6). Application of manure at doses of 10, 20 and 30 tons per hectare has not caused a positive response to the physiological character of the plant being tested, indicated by no significant difference in total chlorophyll levels. This can be attributed to nutrient uptake by plants. From the results of the observation, it was seen that the plants tested did not show N, P, K elemental uptake that were significantly different, at various doses of cow manure given (Table 3). Nutrients, especially $\mathrm{N}$, has an influence on chlorophyll levels because chlorophyll synthesis is influenced by various factors such as light, sugar or carbohydrates, water, temperature, genetic factors, nutrients such as $\mathrm{N}, \mathrm{Mg}, \mathrm{Fe}$, $\mathrm{Mn}, \mathrm{Cu}, \mathrm{Zn}, \mathrm{S}$, and $\mathrm{O}[27]$.

Table 6. Total chlorophyll content in leaves, number of leaves, plant height, total dry weight/plant, and dry weight of dried bulbs/ha of various shallots cultivars at various doses of cow manure

\begin{tabular}{|c|c|c|c|c|c|}
\hline & $\begin{array}{c}\text { Total chlorophyll } \\
\text { content in leaves } \\
(\mathrm{mg} / \mathrm{g} \text { of leaves })\end{array}$ & $\begin{array}{c}\text { Number of } \\
\text { leaves } \\
\text { (sheet) }\end{array}$ & $\begin{array}{c}\text { Plant height } \\
(\mathrm{cm})\end{array}$ & $\begin{array}{c}\text { Total dry } \\
\text { weight/plant } \\
(\mathrm{g})\end{array}$ & $\begin{array}{c}\text { The dry weight } \\
\text { of air dried } \\
\text { bulbs/ha (ton) }\end{array}$ \\
\hline \multicolumn{5}{|c|}{ Cultivars } \\
\hline Bauji & $0.58 \mathrm{p}$ & $21.60 \mathrm{p}$ & $18.54 \mathrm{r}$ & $1.63 \mathrm{q}$ & $2.51 \mathrm{r}$ \\
\hline Tajuk & $0.57 \mathrm{pq}$ & $22.82 \mathrm{p}$ & $22.68 \mathrm{q}$ & $2.46 \mathrm{p}$ & $3.27 \mathrm{q}$ \\
\hline Manjoung & $0.53 \mathrm{qr}$ & $23.39 \mathrm{p}$ & $23.88 \mathrm{q}$ & $2.01 \mathrm{pq}$ & $2.61 \mathrm{qr}$ \\
\hline Bima Brebes & $0.52 \mathrm{r}$ & $24.58 \mathrm{p}$ & $28.47 \mathrm{p}$ & $2.61 \mathrm{p}$ & $4.18 \mathrm{p}$ \\
\hline
\end{tabular}


Tuti Setyaningrum., 2018. Physiological properties, growth, and yield of shallot (Allium cepa var. Aggregatum) in coastal sand land with inoculation of Trichoderma asperellum and cow manure American-Eurasian Journal of Sustainable Agriculture. 12(4) October-December 2018, Pages: 25-33. DOI: 10.22587/aejsa.2018.12.4.4

\begin{tabular}{|c|c|c|c|c|c|}
\hline \multicolumn{7}{|c|}{ Manure dosage } \\
\hline 0 ton/ha & $0.55 \mathrm{a}$ & $21.71 \mathrm{a}$ & $20.96 \mathrm{~b}$ & $1.94 \mathrm{a}$ & $2.28 \mathrm{~b}$ \\
\hline $10 \mathrm{ton} / \mathrm{ha}$ & $0.55 \mathrm{a}$ & $22.61 \mathrm{a}$ & $21.36 \mathrm{~b}$ & $1.87 \mathrm{a}$ & $2.55 \mathrm{~b}$ \\
\hline $20 \mathrm{ton} / \mathrm{ha}$ & $0.56 \mathrm{a}$ & $24.39 \mathrm{a}$ & $24.90 \mathrm{a}$ & $2.45 \mathrm{a}$ & $3.66 \mathrm{a}$ \\
\hline $30 \mathrm{ton} / \mathrm{ha}$ & $0.54 \mathrm{a}$ & $23.68 \mathrm{a}$ & $26.35 \mathrm{a}$ & $2.45 \mathrm{a}$ & $4.07 \mathrm{a}$ \\
\hline \multicolumn{6}{|c|}{ Mean values followed by the same letters show no significant difference by DMRT (p: 0.05) } \\
\hline
\end{tabular}

From Table 6, it can be seen that Bauji, Tajuk, Manjoung, and Bima Brebes cultivars have a number of leaves that are not significantly different. Bima Brebes cultivar is the highest plant and has the highest weight of dried bulbs per ha compared to other cultivars, but the total dry weight per plant was not significantly different from Tajuk and Manjoung. Among the four cultivars tested, Bauji cultivars was the lowest plant height, yields the lowest total dry weight per plant and weight of dried bulbs per hectare, but not significantly different from Manjoung cultivar. The variety of plant heights could be influenced by the genetic factors of each of the shallot cultivars. According to Wahid et al. [28], plant height is mainly controlled by the genetic composition of cultivars and can also be influenced by environmental conditions.

The application of manure with doses of 10, 20 and 30 tons per hectare, did not yield the number of leaves and total dry weight per plant which was significantly different from without manure. The application at a rate of 10 tons per hectare has not yield plant height and the weight of air dried bulbs per hectare, which are significantly different from without manure, the addition of doses to 20 tons per hectare can yield higher plants and the weight of dried bulbs per hectare which is heavier than the one with a dose of 10 tons per ha, but the addition to 30 tons per ha resulted in the weight of dried bulbs per ha which was not significantly different at the rate of 20 tons per ha (Table 6).

Bulbs are the main product of shallots. The Bima Brebes cultivar yields the heaviest weight of dried bulbs per hectare compared to other cultivars. According to Harjadi [29], although planted in the same environmental conditions, different plant varieties show different growth and results. The Bima Brebes cultivar also showed heavier total dry weight per plant although not significantly different from Tajuk and Manjoung cultivars. Increased dry matter content is the main growth indicator, the most commonly used, where dry matter is accumulated from photosynthesis, nutrient uptake, and water which is processed through biosynthetic processes which increases with age [30]. Although it has a number of leaves that are not significantly different, but plant height in Bima Brebes cultivars was higher than other cultivars, allowing to be able to capture more sunlight to carry out photosynthesis. Light is very important in the process of photosynthesis because it acts as an energy source, forming dry plant material. The process of photosynthesis will take place well if sunlight falls on the surface of the plant through chlorophyll is optimal, and will be disturbed otherwise [31]. Lots of photosynthates, which will be translocated to the bulb.

\section{CONCLUSION}

The results showed that the treatment of cultivars yield diversity in the total chlorophyll content, plant height, total dry weight per plant and weight of air dried bulbs per hectare.

The Bima Brebes cultivar yield the heaviest weight of dried bulbs per hectare

The dosage of manure of 30 tons per hectare results the heaviest weight of air-dry bulbs even though not significantly different with a dose of 20 tons per hectare

\section{ACKNOWLEDGEMENT}

We would like to express our gratitude to the Directorate of Research and Community Service, Directorate General of Research and Development Strengthening, Ministry of Research and Technology who has assisted the fund in conducting this research through research contract no: 084/SP2H/LT/DRPM/2018

\section{REFERENCES}

[1] BPS. (2015). Distribusi Perdagangan Komoditas Bawang Merah Indonesia 2015. Subdirektorat Statistik Perdagangan Dalam Negeri. Badan Pusat Statistik, Jakarta - Indonesia. 105 hal

[2] Iriani, E. (2013). Prospek pengembangan inovasi teknologi bawang Merah di lahan sub optimal (lahan pasir) Dalam upaya peningkatan pendapatan petani. Jurnal Litbang Provinsi Jawa Tengah, Vol.11 No. 2., $231-243$ 
Tuti Setyaningrum., 2018. Physiological properties, growth, and yield of shallot (Allium cepa var. Aggregatum) in coastal sand land with inoculation of Trichoderma asperellum and cow manure American-Eurasian Journal of Sustainable Agriculture. 12(4) October-December 2018, Pages: 25-33. DOI: 10.22587/aejsa.2018.12.4.4

[3] Yuwono, NW. (2009). Membangun Kesuburan Tanah di Lahan Marginal. Jurnal Ilmu Tanah dan Lingkungan. Vol. 9 No 2 (2009) p: 137-141

[4] Al-Omran, A.M.; A.M. Falatah;A.S. Sheta and A.R.A1-Harbi. (2004). Clay Deposits for Water Management of Sandy Soils. Arid Land Researcha ndM anagementI : 171-I 83.

[5] Ginting, K.E., Lahay, R.R. dan Hanum, C. (2013). Respons pertumbuhan dan produksi bawang merah (Allium ascalonicum L.) terhadap pemberian pupuk NPK dan Tithonia diversifolia. Jurnal Online Agroekoteknologi Vol.1, No.3, Juni 2013. 853 - 863

[6] Yulipriyanto, H. (2010). Biologi tanah dan strategi pengelolaannya. Graha Ilmu, Yogyakarta . xxvi + 258 hlm

[7] Delvian. (2007). Penggunaan Asam Humik dalam Kultur Trapping Cendawan Mikoriza Arbuskula dari Ekosistem dengan Salinitas Tinggi. Departemen Kehutanan Fakultas Pertanian USU, Medan

[8] Scholes, M.C., Swift, O.W., Heal, P.A. Sanchez, JSI., Ingram and R. Dudal. (1994). Soil Fertility research in response to demand for sustainability. In The biologicalmanagemant of tropical soil fertility (Eds Woomer, Pl. and Swift, MJ.) John Wiley \& Sons. New York

[9] Partoyo. (2005). Analisis Indeks Kualitas Tanah Pertanian Di Lahan Pasir Pantai Samas Yogyakarta. Jurnal Ilmu Pertanian 12 (2) : 140-151

[10] Lakshmi, J. Sudha, Kuberan, T., Anburaj, M., Sundaravadivelan, C., Kumar, P. dan Dhanaseeli, Manorama. (2011). Effect of plant growth promoting fungal inoculants on the growth of Arachis hypogeal (L.) and it's role on the induction of systemic resistance against Rhizoctonia solani. Asian Journal of Bio Science Vol. 6 Issue 1: 131 - 139

[11] Shivanna, M. B., Meera, M. S. and Hyakumachi, M. (1994). Sterile fungi from zoysiagrass rhizosphere as plant growth promoters in spring wheat. Can. J. Microbiol 40: $637-644$

[12] Villalobos, S. de los Santos, D.A. Guzman-Ortiz, M.A. Gomez-Lim, J.P. Delano-Frier, S. de-Folter, P. Sanchez-Garcia, J.J. Pena-Cabriales. (2013). Potential use of Trichoderma asperellum (Samuels, Liechfeldt et Nirenberg) T8a as a biological control agent against anthracnose in mango (Mangifera indica L.). Biological Control 64: 37-44

[13] Ozbay, N.and S.E. Newman. (2004). The Effect of the Trichoderma harzianum Strains on the Growth of Tomato Seedlings. Proc. XXVI IHC . Managing Soil-Borne Pathogens. Ed. A. Vanachter. Acta Hort. 635, ISHS 2004. Publication supported by Can. Int. Dev. Agency (CIDA)

[14] Subash, N., Meenakshisundaram, M., Unnamalai, N and Sasikumar, C. (2013). Effect of Trichoderma harizanum to Control Damping Off Disease and Growth Promotion in Chilli (Capsicum annuum ). Int J Pharm Bio Sci 2013 Apr; 4(2): (B) 1076 - 1082

[15] Chamzurni, T., R. Sriwati, dan R. D. Selian. (2011). Efektivitas dosis dan waktu aplikasi Trichoderma virens terhadap serangan Sclerotium rolfsii pada kedelai. J. Floratek 6: 62 - 73

[16] Sharma, P., Patel, A.N., Saini, M.K. and Deep, S. (2012). Field demonstration of Trichoderma harzianum as a plant growth promoter in wheat (Triticum aestivum L.). Journal of Agricultural Science; Vol. 4. No. 8: $65-73$

[17] Rajiman, Yudono, P., Sulistyaningsih, E. dan Hanudin, E., (2008). Pengaruh Pembenah Tanah Terhadap Sifat Fisika Dan Hasil Bawang Merah Pada Lahan Pasir Pantai Bugel. Jurnal Agrin 12 (1): 67-77.

[18] Brady, N.C. (1990). The Nature and Properties of Soil. Mac Millan Publishing Co., New York.

[19] Foth, H D. (1991). Dasar-dasar Ilmu Tanah. Gadjah Mada University Press

[20] Jangiam, W., N. Sangthong, \& K.Soontrapiromsook. (2018). Screening of Microorganisms from Homemade Biofertilizers to Promote Plant Growth. American-Eurasian Journal of Sustainable Agriculture, 12(3): 1-7

[21] Chirinda, N., J.E. Olesen, \& J.R Porter,. (2008). Effects of organic matter input on soil microbial properties and crop yields in conventional and organic cropping systems. 16th IFOAM Organic World Congress, Modena, Italy, June 16-20, 2008 Archived at http://orgprints.org/view/projects/conference.html

[22] Moraj, R., C. Paredes, M.A. Bustamantea, F. Marhuenda-Egea \& M.P. Bernal. (2009). Utilisation of manure composts by high-value crops: Safety and environmental challenges. Bioresource Technology. 100 (22): 5454-5460. http://dx.doi.org/10.1016/j.biortech.2008.12.007

[23] Sridianti. (2016). 7 Ciri-ciri dan Klasifikasi Jamur (Fungi). http://www.sridianti.com/ciri-ciri-klasifikasijamur.html. Diunggah 05/03/2016. Diunduh 5/26/2016

[24] Atmojo, S.W. (2003). Peranan bahan organik terhadap kesuburan tanah dan upaya pengelolaannya. Pidato pengukuhan guru besar. Sebelas Maret University Press. 35p.

[25] Cornell University Agronomy Fact Sheet. (2007). Cation Exchange Capacity (CEC). Fact Sheet 22 , Agronomy Fact Sheet Series. Department of Crop and Soil Sciences. College of Agriculture and Life Sciences. Nutrient Management Spear Program http://nmsp.css.cornell.edu 
Tuti Setyaningrum., 2018. Physiological properties, growth, and yield of shallot (Allium cepa var. Aggregatum) in coastal sand land with inoculation of Trichoderma asperellum and cow manure American-Eurasian Journal of Sustainable Agriculture. 12(4) October-December 2018, Pages: 25-33. DOI: 10.22587/aejsa.2018.12.4.4

[26] Suherman, F. (2013). Pertumbuhan dan Kandungan Klorofil pada Capsicum annum L. dan Licopersicon esculentum yang Terpapar Pestisida. Universitas Pendidikan Indonesia, Bandung.

[27] Hendriyani, I. S \& N. Setiari. (2009). Kandungan Klorofil dan Pertumbuhan Kacang Panjang (Vigna sinensis) pada Tingkat Penyediaan Air yang Berbeda. J. Sains \& Mat. 17(3): 145-150.

[28] Wahid, S.A., I. H.H. Al-Hilfy \& H.M.K. Al-Abodi. (2017). Effect of sowing dates on the growth and yield of different wheat cultivars and their relationship with accumulated heat units. American-Eurasian Journal of Sustainable Agriculture, 11(3): 7-13

[29] Harjadi, S.S. (1991) . Pengantar Agronomi. PT. Gramedia. Jakarta.

[30] Sitompul, S.M. dan B. Guritno. (1995). Analisis PertumbuhanTanaman. Gadjah Mada University Press, Yogyakarta.

[31] Sawen, D. (2012). Pertumbuhan rumput gajah (Pennisetum purpureum) dan benggala (Panicum maximum) akibat perbedaan intensitas cahaya .Agrinimal 2: 17-20. 